Misr J. Ag. Eng., 26(1): 251- 281

PROCESS ENGINEERING

\title{
THIN LAYER DRYING OF GARLIC SLICES USING CONVECTION AND COMBINED (CONVECTION - INFRARED) HEATING MODES
}

\author{
A. Abdelmotaleb. ${ }^{1}$; M. M. El-Kholy ${ }^{2}$; N. H. Abou-El-Hana ${ }^{3}$; \\ and M. A.Younis ${ }^{4}$.
}

\begin{abstract}
Thin layer drying of garlic slices has been studied under convection and combined infrared-convection heating modes. Four levels of inlet air temperature $45,55,65$, and $75^{\circ} \mathrm{C}$ and three levels of air velocity of 0.25 , 0.75 , and $1.25 \mathrm{~m} / \mathrm{s}$ were used for the convection drying experiments. While, for the combined infrared-convection, three levels of radiation intensity of about 0.075, 0.15 and $0.225 \mathrm{~W} \mathrm{~cm}^{-2}$ and three levels of air temperatures 45, 55 and $65^{\circ} \mathrm{C}$ were studied at inlet air velocity of 0.75 $\mathrm{m} / \mathrm{s}$. Three mathematical models (Page, Modified Page, and Henderson and Pabis) were examined for describing the drying behavior of garlic slices under the above mentioned experimental parameters. The results were compared to their goodness of fit in terms of coefficient of determination $\left(R^{2}\right)$, Standard deviation $(S D)$, average percentage of error $(\% E)$, chi-square $\left(\chi^{2}\right)$ and the modeling efficiency $(E F)$. The results showed increases in drying rate, thermal efficiency, rehydration ratio, flavor strength, and colour difference, and showed decreases in drying time and specific energy consumption for the combined (infraredconvection) heating mode in comparison with convection only. The Page model satisfactorily described the drying behavior of garlic slices and predicted the changes in garlic slices moisture content as compared with the modified Page and the Henderson and Pabis models. Meanwhile, for the convection heating mode, the drying constant $(k)$ increased with the
\end{abstract}

(1)- Prof., and Head of Ag. Eng. Dept., Fac. of Ag., Kaferelsheikh Univ.

(2)- Senior Researcher, Ag. Eng. Res. Institute, Ag. Res. Center, Dokki,

(3)- Lecturer, Ag. Eng. Dept., Fac. of Ag., Kaferelsheikh Univ.

(4)- Ag. Eng., Ag. Eng. Res. Institute, Ag. Res. Center, Dokki, Giza. 
increase of air temperature and air velocity while, the constant (n) decreased, while, for the combined mode, the drying constant $(k)$ increased with the increase of radiation intensity and air temperature. However, the constant (n) decreased.

\section{INTRODUCTION}

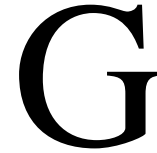
arlic (Allium Sativum) is a vegetable spice used for seasoning of foods because of its typical pungent flavor. It is usually used without any preprocessing operation. More recently, it has been used in its dried form, as an ingredient of precooked foods and instant convenience foods including sauces, gravies and soups, which led to a sharp increase in the demand of dried garlic (Sharma and Prasad, 2006). Afzal and Abe (2000) reported that air velocity during convective grain drying in thin layers has little influence (would normally increase although may not substantial) on the moisture removal rate, Jayas and Sokhansanj (1989). Contrary to convective drying, an increase in air velocity during far infrared (FIR) drying of barley decreased the drying rate. Increasing air velocity at a given radiation intensity resulted in lowering of kernel temperature and hence, the drying rate.

Afzal et al. (1999) dried barley in thin layers both under combined FIRconvection and convection alone. The experimental results show that the use of far infrared radiation enhances the drying rate and the energy consumption was reduced considerably. An intensity level of 0.333 $\mathrm{W} / \mathrm{cm}^{2}$ was found to be optimum for radiation drying. Air velocity showed a strong effect on energy consumption.

Hebbar et al. (2004) developed a combined infrared and hot air heating system for drying of vegetables. The system was designed to operate under infrared, hot air and combination mode independently. The performance evaluation studies indicated that combination drying of carrot and potato at $80{ }^{\circ} \mathrm{C}$ with air at a velocity of $1 \mathrm{~m} / \mathrm{s}$ and temperature of $40{ }^{\circ} \mathrm{C}$ reduced the drying time by $48 \%$, besides consuming less energy (63\%) compared to hot air heating.

Madamba et al.(1996) investigated thin-layer drying of garlic slices (2-4 $\mathrm{mm}$ ) for a temperature range $50-90{ }^{\circ} \mathrm{C}$, a relative humidity range $8-24 \%$, and an airflow range $0.5-1 \mathrm{~m} / \mathrm{s}$. An analysis of variance (ANOVA) revealed that temperature and slice thickness significantly affected the 
drying rate while relative humidity and airflow rate were insignificant factors during drying. Four mathematical models available in the literature were fitted to the experimental data, Page and the twocompartment models gave better predictions than the single-term exponential and Thompson's model. Doymaz (2004) investigated the effects of air temperature, air-flow rate and sample thickness on drying kinetics of carrot cubes. Convective air drying of carrot cubes were evaluated in a cabinet dryer. Drying was carried out at 50, 60, 65, $70{ }^{\circ} \mathrm{C}$. Two mathematical models available in the literature were fitted to the experimental data. The Page model showed better prediction than the Henderson and Pabis model and satisfactorily described drying behaviour of carrot cubes.

The purpose of the present study was to test and to evaluate the effect of different levels of infrared radiation intensity and air velocity on drying characteristics and quality changes of thin layer garlic slices under convection and combined heating modes.

\section{MATERIALS AND METHODS}

Freshly-harvested garlic cloves (Allium Sativum) used for the experimental work. The initial moisture content of the freshly harvested garlic ranged from $69 \%$ to $72 \%$ (wet basis) and the drying experiments for each were stopped when the final moisture content reached about $6 \%$ (w.b.).

The experimental apparatus used for the drying process is shown in Figure (1). The drying box constructed of $1.5 \mathrm{~mm}$ galvanized metal sheet with $40 \times 28 \mathrm{~cm}$ cross section and $40 \mathrm{~cm}$ high. It was covered from inside with aluminum foil sheets. Two infrared halogen lamps $(500 \mathrm{~W})$ were used as a source of infrared radiation. The drying box connected with two electric heaters of $1.35 \mathrm{~kW}$ for each. The size of sample holding tray was $20 \times 20 \times 1 \mathrm{~cm}$. It was placed facing the infrared lamps at a distance of 15 $\mathrm{cm}$ and supported on an electronic balance to enable recording the mass change of sample during the drying process.

The experiments of the convection mode were conducted at three levels of inlet air temperature $\left(45,55,65\right.$, and $\left.75^{\circ} \mathrm{C}\right)$ and three levels of air velocity which are of about $(0.25,0.75$, and $1.25 \mathrm{~m} / \mathrm{s})$. However, the 


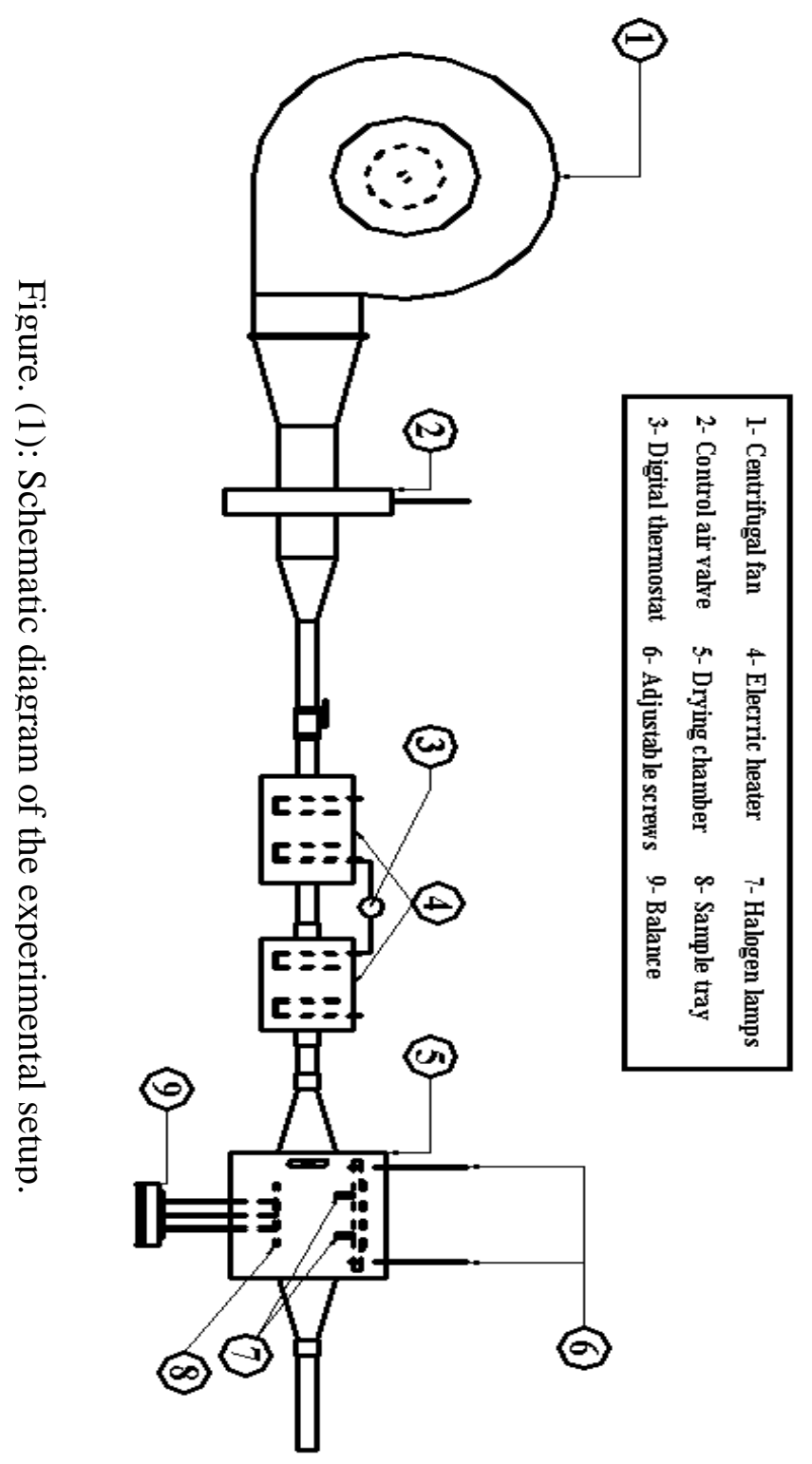

Misr J. Ag. Eng., January 2009 
experiments of combined infrared-convection mode were conducted at three levels of radiation intensity of about $0.075,0.15$ and $0.225 \mathrm{~W} / \mathrm{cm}^{2}$, three levels of air temperatures of about $\left(45,55\right.$ and $\left.65^{\circ} \mathrm{C}\right)$ and constant inlet air velocity of $0.75 \mathrm{~m} \mathrm{~s}^{-1}$. The observations on mass loss changes were recorded until the product reached about $6 \%$ (w.b) without removing the sample from the drying box. A sample size of $100 \mathrm{~g}$ garlic slices was used in each drying run. The peeled cloves were sliced to the desired thicknesses of $(2.5 \pm 0.5 \mathrm{~mm})$. The mass of the samples was recorded using a digital balance with an accuracy of $0.01 \mathrm{~g}$. The balance used for determining the initial and the final mass of sample, and the mass changes through out the experimental runs. The mass changes measurements were used for calculating the change of samples moisture content in wet bases. While, the initial moisture content of garlic were determined on a wet basis by the method described by A.O.AC. (1995) using a vacuum oven at $70^{\circ} \mathrm{C}$ and gauge pressure of $85 \mathrm{kPa}$ for $24 \mathrm{~h}$.

\section{The Examined Drying Models for Simulating the Drying Data:}

To find the most convenient drying model describing the drying behaviour of garlic slices, as shown in Table (1) the three different drying models were examined for fitting the drying data. The moisture ratio is usually expressed as $\left(\mathrm{M}-\mathrm{M}_{\mathrm{e}}\right) /\left(\mathrm{M}_{\mathrm{o}}-\mathrm{M}_{\mathrm{e}}\right)$. However, it could be simplified to $\mathrm{M} / \mathrm{M}_{\mathrm{o}}$, due to the continuous fluctuation of the relative humidity of the drying under the tested drying conditions (Yaldiz and Ertekin, 2001). Also, $\mathrm{M}_{\mathrm{e}}$ value was relatively small compared to $\mathrm{M}$ and $\mathrm{M}_{0}$ (Sacilik and Unal, 2005). Regression analysis was done by using the statistical routine. The results were compared to their goodness of fit in terms of coefficient of determination $\left(\mathrm{R}^{2}\right)$, Standard deviation (SD), the average percentage of error $(\% \mathrm{E})$, Chi-square $\left(\chi^{2}\right)$ and the modeling efficiency (EF). A model is considered to be good when the correlation coefficient $\left(\mathrm{R}^{2}\right)$ and modeling efficiency (EF) are higher and the standard deviation (SD), the average percentage of error $(\% \mathrm{E})$, chi-square $\left(\chi^{2}\right)$ are lower (Ramesh (2000). The regression analysis was also used to develop mathematical relationships between the experimental parameters and predicting the moisture content. 
Table (1): The examined mathematical models used for describing the drying data.

\begin{tabular}{|l|l|l|}
\hline \multicolumn{1}{|c|}{ Model } & \multicolumn{1}{|c|}{ Equation } & \multicolumn{1}{c|}{ References } \\
\hline Page & $M R=\exp \left(-k t^{n}\right)$ & Page (1949) \\
\hline Modified Page & $M R=\exp \left(-(k t)^{n}\right)$ & Overhults et al. (1973) \\
\hline Henderson and Pabis & $M R=a \exp (-k t)$ & Henderson and Pabis (1961) \\
\hline
\end{tabular}

where:

$\mathrm{MR}=$ Moisture ratio;

$\mathrm{M}=$ Moisture content, \%(w.b.) at time t;

Mo = Initial moisture content at zero time, \%(w.b.);

$\mathrm{Me}=$ Equilibrium moisture content, \% (w.b.) and

$\mathrm{K}, \mathrm{n}, \mathrm{a}=$ Drying constants.

\section{Energy Requirement:}

The energy consumption during the drying process is the sum of the energy required for heating the ambient air and the net infrared energy supplied. For each experimental run the power, consumption was calculated using the following relationship (Afazl et al., 1999):

$$
\text { power }=I \times V \times P F
$$

Where:

$$
\begin{aligned}
& \text { Power }=\text { Power consumption, }(\mathrm{W}) ; \\
& V \quad=\text { Voltage },(\mathrm{v}) ; \\
& I \quad=\text { Amperage },(\mathrm{A}) \text { and } \\
& P F \quad=\text { Power factor, assumed to be one. }
\end{aligned}
$$

The consumed energy was also related to the quantity of lost water and expressed as energy consumption rate (specific energy consumption) in $\mathrm{MJ} / \mathrm{kg}$ of water.

\section{Thermal Efficiency:}

The thermal efficiency was calculated using the following relationship according to (Reys and Jindal, 1986)

$$
E_{t}=\left(W_{W} \times \frac{L h}{Q}\right) \times 100
$$

Where:

$\mathrm{E}_{\mathrm{t}}=$ Thermal efficiency, \%;

$\mathrm{W}_{\mathrm{W}}=$ Water evaporated from the product, $\mathrm{kg}$; 
$\mathrm{Lh}=$ Latent heat of evaporation of water, $\mathrm{kJ} / \mathrm{kg}$; and

$\mathrm{Q}=$ Total energy consumption, $\mathrm{kJ}$.

Latent heat of product was calculated according to the following formula (Hall, 1970):

$$
\frac{\text { Latent heat of proudct }}{\text { Latentheat of free water }}=1+23 e^{-0.4 M}
$$

Where:

$$
\mathrm{M}=\text { Moisture content \%, (d.b.). }
$$

\section{Rehydration ratio measurement:}

Rehydration ratio of the dried garlic slices was determined in triplicate. The rehydration capacity was evaluated by immersing $5 \mathrm{~g}$ of dried samples into $250 \mathrm{ml}$ laboratory glass containing $150 \mathrm{ml}$ of distilled water and then boiled for $3 \mathrm{~min}$. Sample was taken out, blotted with paper towel to eliminate surface water and then reweighed (Sacilik and Unal, 2005). The rehydration ratio was calculated using equation (8).

where: $\quad$ Rehydration ratio $=\left(\frac{W_{t}-W_{d}}{W_{d}}\right)$

$$
\begin{aligned}
& \mathrm{W}_{\mathrm{t}}=\text { Weight of the rehydrated sample, }(\mathrm{g}) \text {, and } \\
& \mathrm{W}_{\mathrm{d}}=\text { Weight of the dried sample, }(\mathrm{g}) .
\end{aligned}
$$

\section{Flavor strength measurement:}

The volatile oil comprising of sulfur compounds which are responsible for pungency of the garlic was determined by Chloramine-T method (Shankaranarayana et al., 1981). The volatile oils in the samples were expressed as mg oil/g dry matter.

\section{Colour of the dried garlic:}

The appearance of both fresh and dehydrated slices was assessed by a colour-difference meter using a Hunter Lab Colorimeter. The colorimeter was calibrated against a standard calibration plate of a white surface with L, a, b values of $91.10-0.64$ and -0.43 respectively. (Sharma and Prasad, 2006).

Colour difference $\Delta \mathrm{E}$ and hue angle $\mathrm{H}$ were determined using the following equations: 


$$
\begin{aligned}
& \Delta \mathrm{E}=\sqrt{\left(\mathrm{L}_{0}-L_{f}\right)^{2}+\left(a_{0}-a_{f}\right)^{2}+\left(b_{0}+b_{f}\right)^{2}} \\
& H=\tan ^{-1}\left(\frac{b}{a}\right)
\end{aligned}
$$

where: $\Delta \mathrm{E}$ is the colour difference; $\mathrm{H}$ is the hue angle in degree; $\mathrm{L}_{0}$, a and $b_{0}$ are the colour lightness, green-red and blue-yellow chromaticity of raw garlic; and $\mathrm{L}_{\mathrm{f}}$, $\mathrm{af}_{\mathrm{f}}$ and $\mathrm{b}_{\mathrm{f}}$ are the colour lightness, green-red and blueyellow chromaticity of dehydrated garlic, respectively. The raw garlic slices were used as the reference and a higher $\Delta \mathrm{E}$ stand for greater colour change from the reference material. The values of $0,90,180$ and $270^{\circ}$ for $\mathrm{H}$ represent red, yellow, green and blue, respectively.

\section{RESULTS AND DISCUSSION}

\section{Drying behavior of garlic slices under different heating modes:}

Figure (2) presents the garlic slices temperature increased with the increase of drying time. Increasing the air temperature and the air velocity tended to increase the garlic slices temperature. This is due to fast and more addition of heat to the garlic slices. At the minimum air velocity of $0.25 \mathrm{~m} / \mathrm{s}$ the overall average slices temperatures during the drying process were $29.9,38.7,51.1$ and $52.1{ }^{\circ} \mathrm{C}$ at the minimum air temperature of 45 ${ }^{\circ} \mathrm{C}$, while, at the maximum air velocity of $1.25 \mathrm{~m} / \mathrm{s}$ the corresponding slices temperature were $35.2,44,56.3$ and $66.2{ }^{\circ} \mathrm{C}$ at maximum air temperature of $75^{\circ} \mathrm{C}$.

Figure (3) presents the garlic slices temperature increased with the increase of drying time. Increasing the air temperature and radiation intensity tended to increase the garlic slices temperature. At the minimum air temperature of $45^{\circ} \mathrm{C}$ the overall average slices temperatures during the drying process were $74.6,83.1$ and $88.3{ }^{\circ} \mathrm{C}$ at the minimum radiation intensity of $0.075 \mathrm{~W} / \mathrm{cm} 2$, while, at the maximum air temperature of 65 ${ }^{\circ} \mathrm{C} \mathrm{m} / \mathrm{s}$ the corresponding slices temperature were $86.7,97.6$ and $108.1{ }^{\circ} \mathrm{C}$ at maximum air temperature of $0.225 \mathrm{~W} / \mathrm{cm}^{2}$. 


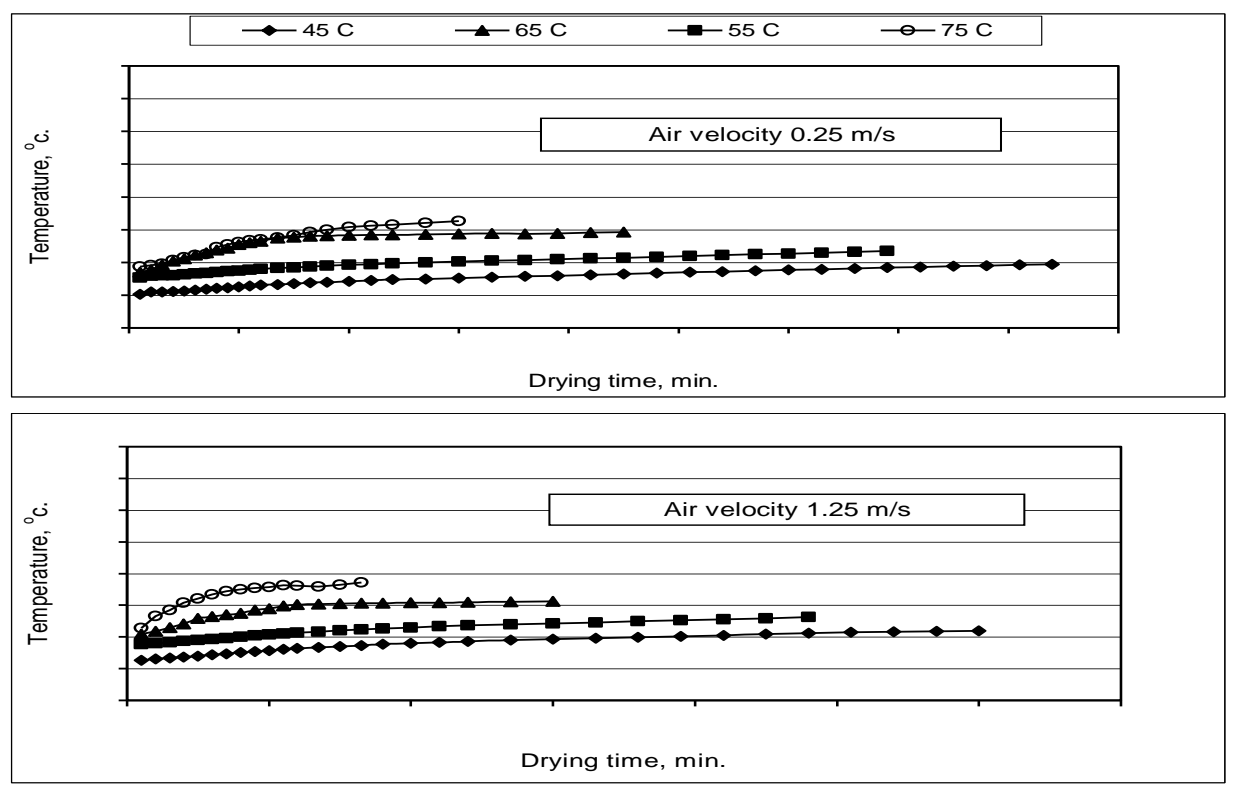

Figure (2): Slices temperature at different air temperature and air velocity.
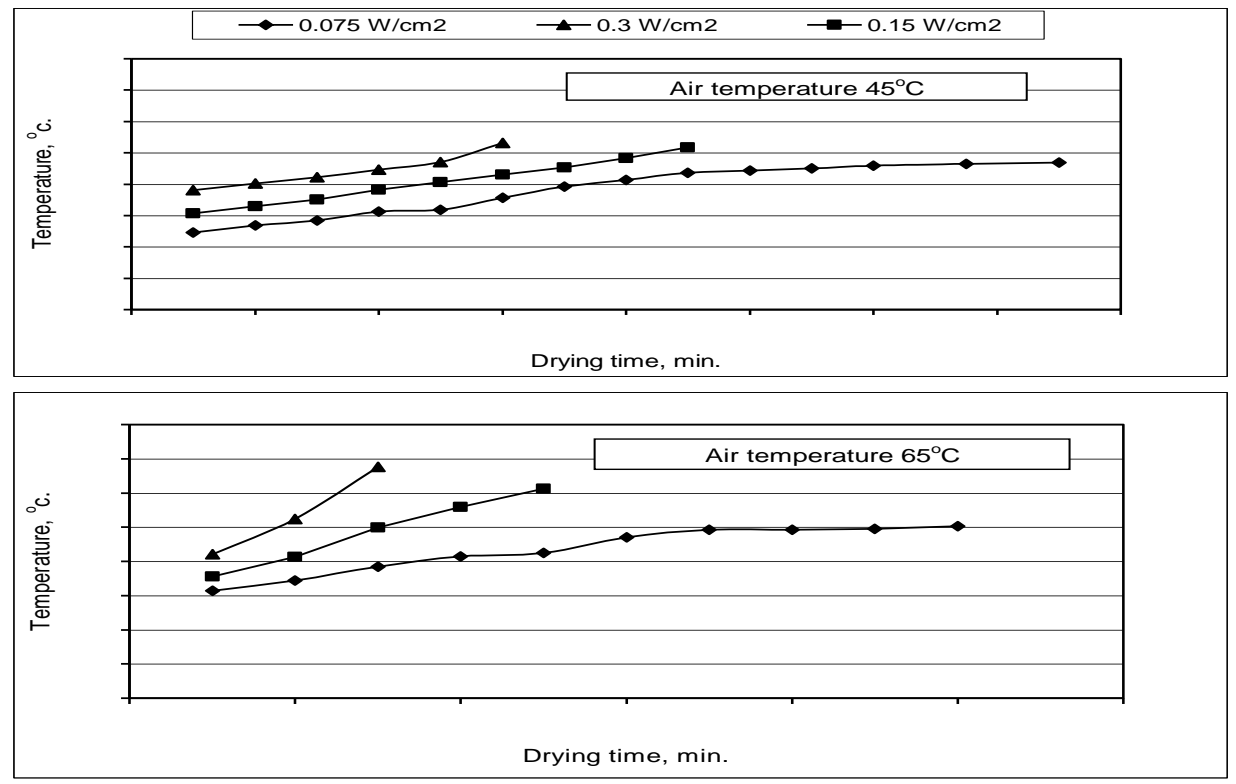

Figure (3): Slices temperature at different radiation intensity and air temperature.

Misr J. Ag. Eng., January 2009 
Figure (4) and (5) present the change in moisture ratio of garlic slices as related to drying time for the convection and the combined heating modes. For the convection mode, the moisture ratio decreased with the increase of drying time and the reduction rate of moisture increased with the increase of drying air temperature and air velocity. However, for the combined infrared-convection mode, the moisture ratio decreased with the increase of drying time and the reduction rate was higher for the samples treated with higher radiation intensity and higher air temperature. In general, the reduction of moisture ratio was higher for the samples dried under the combined heating as compared to convection alone. For the convection drying mode, changing the air temperature from 45 to 75 ${ }^{\circ} \mathrm{C}$ at the minimum air velocity of $0.25 \mathrm{~m} / \mathrm{s}$ decreased the drying time from 840 to $300 \mathrm{~min}$. While, at the maximum air velocity of $1.25 \mathrm{~m} / \mathrm{s}$ the drying time decreased from 600 to $165 \mathrm{~min}$. While, for the combined heating mode at the minimum air temperature of $45{ }^{\circ} \mathrm{C}$ changing the radiation intensity from 0.075 to $0.225 \mathrm{~W} / \mathrm{cm}^{2}$ decreased the drying time from 135 to $40 \mathrm{~min}$. While, at the maximum air temperature of $65{ }^{\circ} \mathrm{C}$ the drying time decreased from 100 to $25 \mathrm{~min}$.

\section{Evaluation of the examined drying models:}

In order to predict the changes in moisture content of garlic slices as a function of drying time, Page, modified Page and Henderson and Pabis models were examined.

To visualize the suitable mathematical expressions, the three models were linearized as follows:

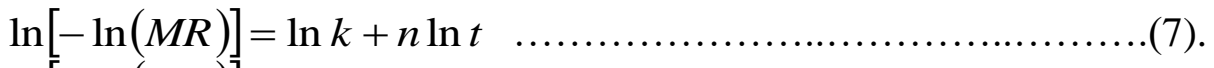

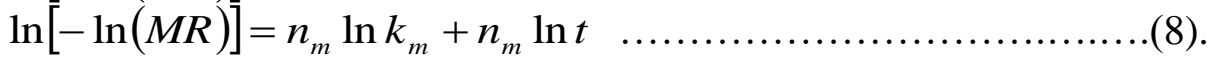

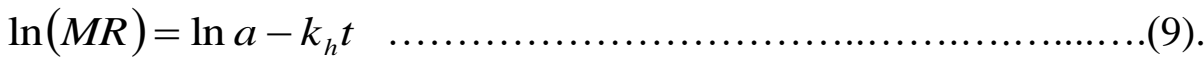

The multiple linear regression analysis was used to develop relationships between the parameters of each model and the drying treatments.

Drying constants of Page and the modified page models were obtained by applying linear regression analysis to the values $\ln (-\ln (\mathrm{MR}))$ and the corresponding drying time (Equations 7 and 9). For the page model, the slope of the fitted line represented the constant (n), while the intercept represents the value of constant $(\mathrm{k})$. While, for the modified page model, 


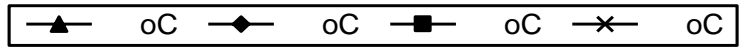

Air temperature
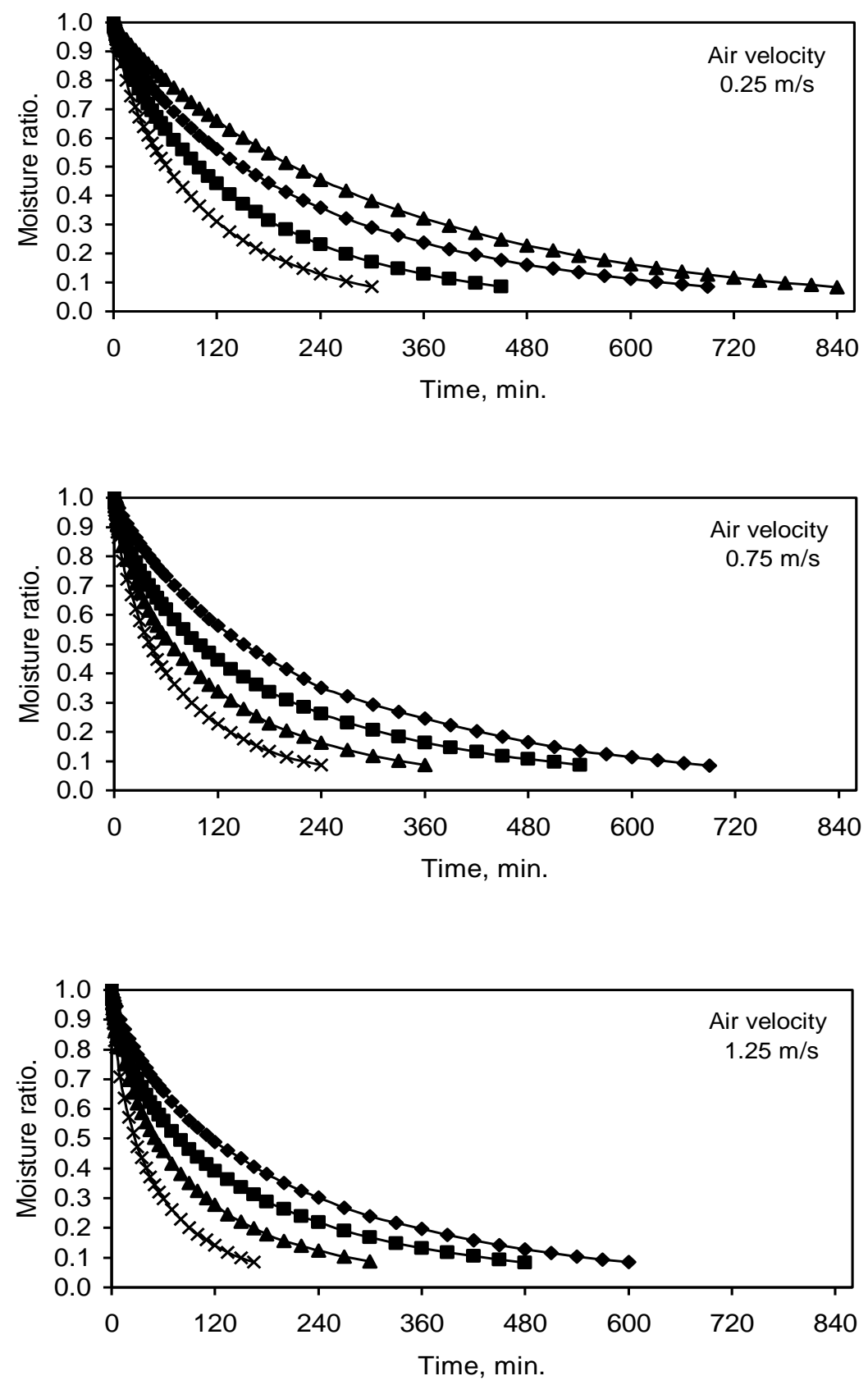

Figure (4): Moisture ratio as related to drying time for the convection mode at different air temperature and different air velocity 

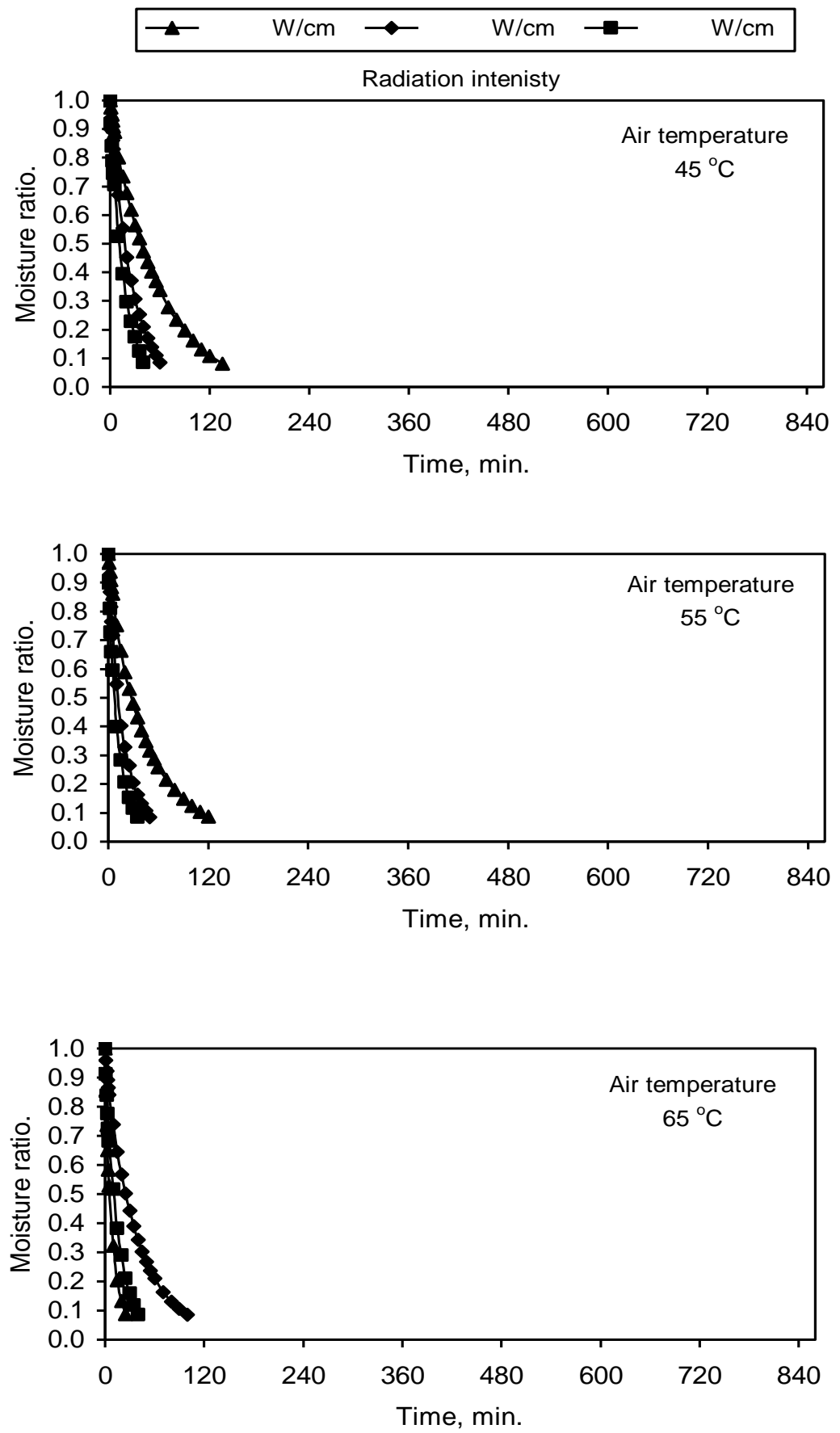

Figure (5): Moisture ratio as related to drying time for the combined mode at different radiation intensity and different air temperature. 
the slope of the fitted line represented the constant $\left(\mathrm{n}_{\mathrm{m}}\right)$, while the intercept represents the value of the constant $\left(\mathrm{k}_{\mathrm{m}}\right)=\left(\mathrm{n}_{\mathrm{m}} \ln \mathrm{k}_{\mathrm{m}}\right) / \mathrm{n}_{\mathrm{m}}$.

However, the value of the drying constant of the modified Henderson and Pabis model $\left(\mathrm{k}_{\mathrm{h}}\right)$ and (a) was obtained by applying linear regression analysis to the values $\ln (\mathrm{MR})$ and the corresponding drying time (Equation 9). The slope of the fitted line represented the constant $\left(\mathrm{k}_{\mathrm{h}}\right)$, while the intercept represents constant (a).

\section{Convection heating mode:}

The statistical analysis used for data fitting for the three models are summarized in Table 2. As shown in this table, all the studied models gave consistently high coefficient of determination $\left(\mathrm{R}^{2}\right)$ in the range $0.9887-0.9997$. This means that all the three models could satisfactorily describe the drying behaviour of garlic slices under convection heating mode. However, among the three models, Page model showed the highest coefficient of determination $\left(\mathrm{R}^{2}\right)$ of 0.9997 and the highest modeling efficiency (EF) of 0.9998 and the lowest standard deviation (SD) of 0.0034 , the lowest average percentage error (E) of 0.0144 and the lowest Chi-square $\left(\chi^{2}\right)$ of 0.000014 . The experimental and predicted values of moisture ratio as related to drying time for different studied models are shown in Figure 6. As it can be seen from the figure, the Page model provided a good agreement between the experimental and the predicted data in comparison with other studied models.

On the other hand, as shown in Figures (7) and (8), the drying constants of page model $(\mathrm{k})$ increased with the increase of air temperature and air velocity, while, the constant (n) decreased. A simple regression analysis was employed to relate the drying parameters with the drying constants (k) and (n). The obtained relationships were as follows:

$$
\begin{array}{r}
k_{\text {Page }}=-0.065+2.47 \times 10^{-2} V+1.22 \times 10^{-3} T \quad \ldots \ldots \ldots \ldots \\
\mathrm{R}^{2}=0.8968 \\
n_{\text {Page }}=1.09-0.115 \mathrm{~V}-3.67 \times 10^{-3} \mathrm{~T} \quad \ldots \ldots \ldots \ldots \ldots \ldots \ldots \ldots \ldots \ldots \ldots \ldots
\end{array}
$$

\section{The combined heating mode:}

The statistical analysis used for data fitting for the three models are summarized in Table (3). As shown in the table, all the studied models gave consistently high coefficient of determination $\left(\mathrm{R}^{2}\right)$ in the range of 
Table(2): Statistical results obtained from different thin layer drying models and the drying constants for convection drying.

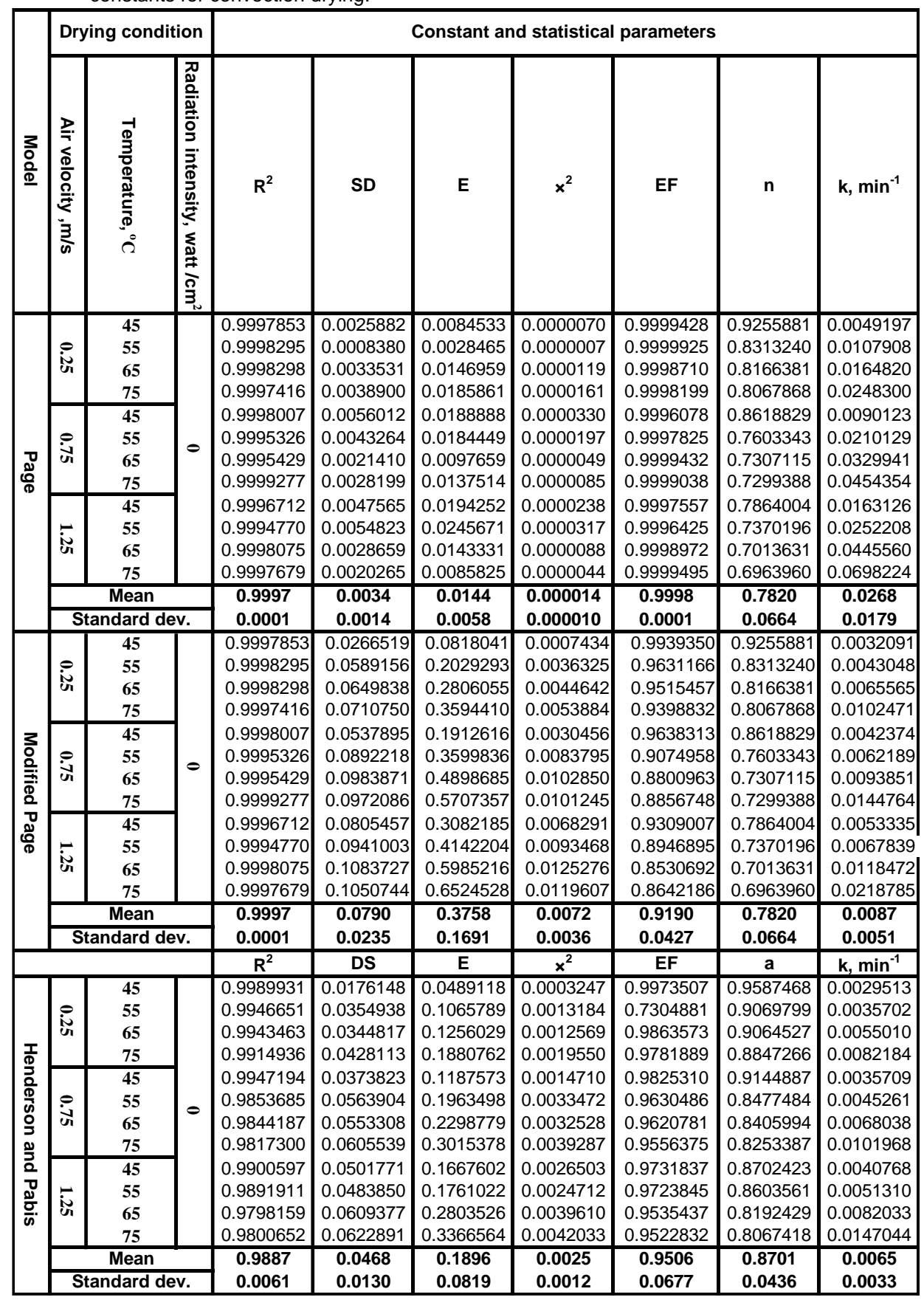



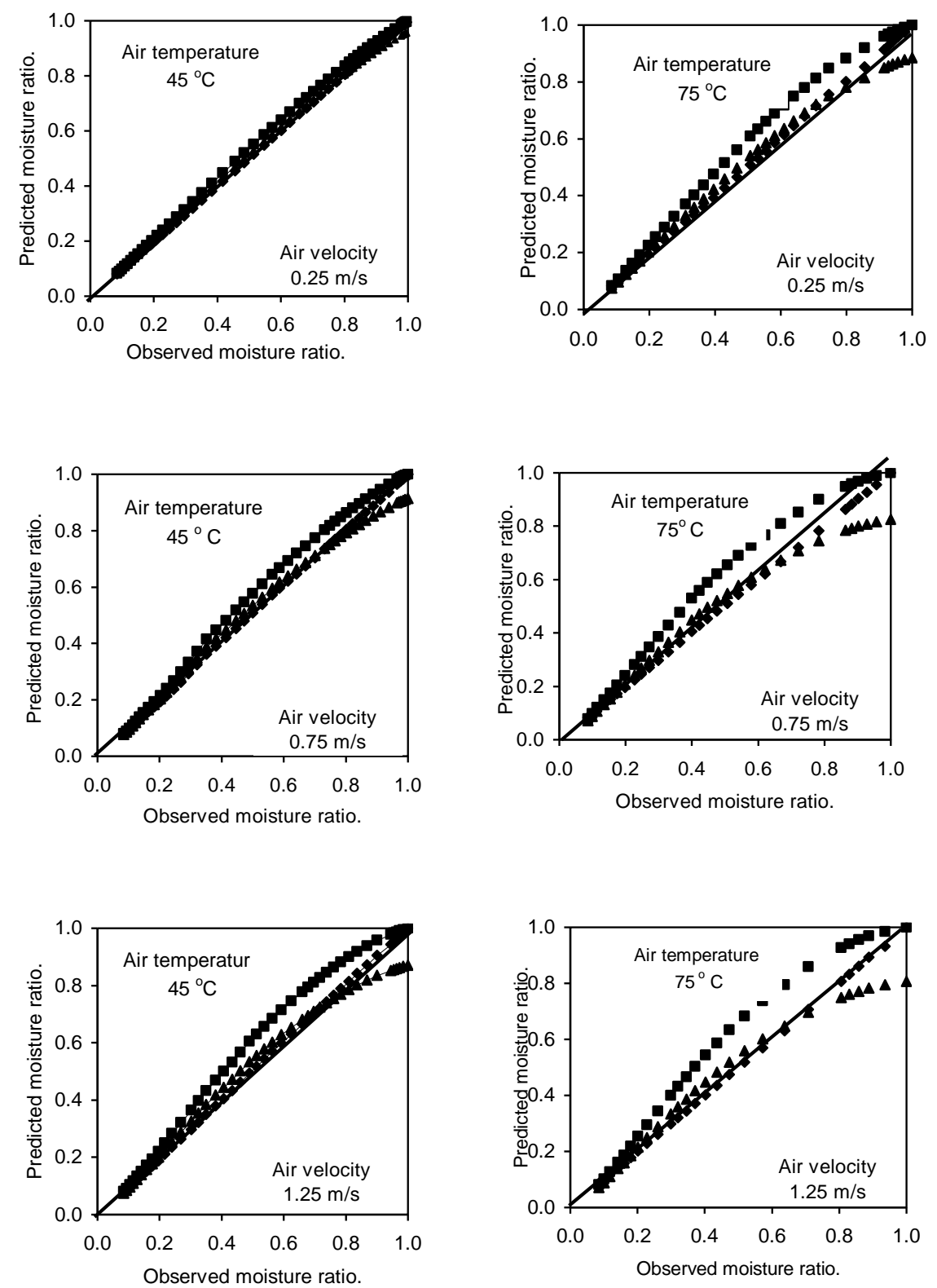

Figure (6): Observed and predicted moisture ratio of the convection heating mode for different studied models. 


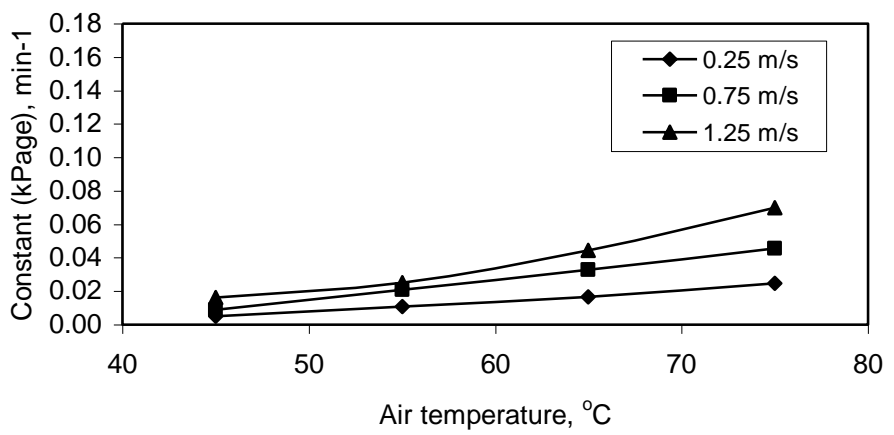

Figure (7): The drying constant $\left(\mathrm{k}_{\text {page }}\right)$ as related to air temperature and air velocity.

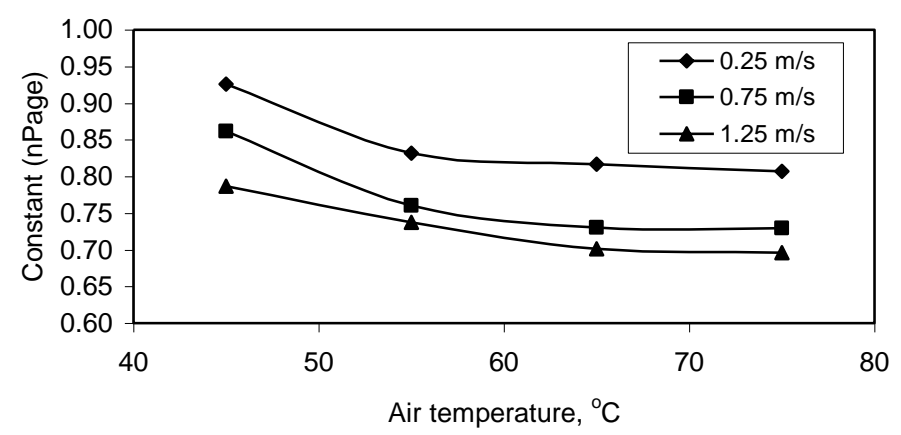

Figure (8): The drying constant $\left(\mathrm{n}_{\text {page }}\right)$ as related to air temperature and

0.9972-0.9988. This means that all the models could satisfactorily describe the drying behaviour of garlic slices using the combined infrared - convection heating mode. However, among the three studied models, the Page model showed the highest coefficient of determination $\left(\mathrm{R}^{2}\right)$ of 0.9988, the highest modeling efficiency (EF) of 0.9934, the lowest standard deviation (SD) of 0.0154, the lowest average percentage of error (E) of 0.1479 and the lowest chi-square $\left(\chi^{2}\right)$ of 0.0007 . Plots of the experimental and the predicted data of the moisture ratio with drying time obtained by the three models are shown in Figure (9). As it can be seen from this figure, the Page model provided a good agreement between the experimental and the predicted data in comparison with other studied models. On the other hands, as shown in Figures (10) and (11), the drying constant $(\mathrm{k})$ increased with the increase of radiation intensity and air temperature while, the constant (n) decreased. A simple regression analysis was employed to relate the drying parameters with 
Table(3): Statistical results obtained from different thin layer drying models and the drying constants for combind infrared and convection drying.

\begin{tabular}{|c|c|c|c|c|c|c|c|c|c|c|}
\hline \multirow[b]{2}{*}{$\begin{array}{l}z \\
\mathbf{3} \\
\stackrel{0}{0} \\
\underline{0}\end{array}$} & \multicolumn{3}{|c|}{ Drying condition } & \multicolumn{7}{|c|}{ Constant and statistical parameters } \\
\hline & 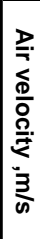 & 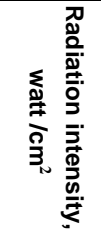 & 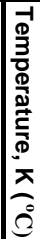 & $\mathbf{R}^{2}$ & SD & E & $x^{2}$ & EF & $\mathbf{n}$ & $k, \min ^{-1}$ \\
\hline \multirow{11}{*}{ ॠ } & \multirow{9}{*}{ 总 } & 0.075 & & 0.9993392 & 0.0194325 & 0.1278583 & 0.0004120 & 0.9957001 & 0.9159103 & 0.0261972 \\
\hline & & 0.15 & 芹 & 0.9967611 & 0.0669808 & 0.6286754 & 0.0050846 & 0.9487650 & 0.8974792 & 0.0566806 \\
\hline & & 0.225 & & 0.9985549 & 0.0090970 & 0.1118720 & 0.0000978 & 0.9991477 & 0.8822242 & 0.0880953 \\
\hline & & 0.075 & & 0.9995429 & 0.0051748 & 0.0329973 & 0.0000293 & 0.9997152 & 0.8921305 & 0.0350570 \\
\hline & & 0.15 & 岁 & 0.9996990 & 0.0059530 & 0.0440519 & 0.0000409 & 0.9996546 & 0.8840292 & 0.0783789 \\
\hline & & 0.225 & & 0.9971041 & 0.0120772 & 0.1680020 & 0.0001750 & 0.9985087 & 0.8658837 & 0.1185686 \\
\hline & & 0.075 & & 0.9995723 & 0.0061302 & 0.0459524 & 0.0000415 & 0.9996030 & 0.8805241 & 0.0418994 \\
\hline & & 0.15 & भi & 0.9991250 & 0.0085451 & 0.0917423 & 0.0000863 & 0.9992548 & 0.8743155 & 0.0936095 \\
\hline & & 0.225 & & 0.9990771 & 0.0051432 & 0.0800022 & 0.0000331 & 0.9998257 & 0.8394703 & 0.1649085 \\
\hline & \multicolumn{3}{|c|}{ Mean } & 0.9988 & 0.0154 & 0.1479 & 0.0007 & 0.9934 & 0.8813 & 0.0782 \\
\hline & \multicolumn{3}{|c|}{ Standard dev. } & 0.0010 & 0.0187 & 0.1749 & 0.0016 & 0.0158 & 0.0201 & 0.0419 \\
\hline \multirow{11}{*}{ 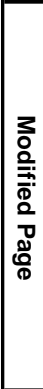 } & \multirow{9}{*}{$P_{i}^{*}$} & 0.075 & & 0.9993392 & 0.0247098 & 0.1793288 & 0.0006661 & 0.9933317 & 0.9159103 & 0.0187514 \\
\hline & & 0.15 & 兵 & 0.9967611 & 0.0986544 & 1.0591712 & 0.0110304 & 0.9039254 & 0.8974792 & 0.0408355 \\
\hline & & 0.225 & & 0.9985549 & 0.0365544 & 0.4671106 & 0.0015792 & 0.9774140 & 0.8822242 & 0.0636942 \\
\hline & & 0.075 & & 0.9990827 & 0.0328961 & 0.2337016 & 0.0011852 & 0.9884900 & 0.8921305 & 0.0238150 \\
\hline & & 0.15 & ú & 0.9996990 & 0.0394205 & 0.4268592 & 0.0017931 & 0.9848560 & 0.8840292 & 0.0561223 \\
\hline & & 0.225 & & 0.9971041 & 0.0539760 & 0.7152605 & 0.0034961 & 0.9702122 & 0.8658837 & 0.0852192 \\
\hline & & 0.075 & & 0.9995723 & 0.0360709 & 0.3078308 & 0.0014381 & 0.9862532 & 0.8805241 & 0.0272433 \\
\hline & & 0.15 & भi & 0.9991250 & 0.0402945 & 0.5090531 & 0.0001902 & 0.9833727 & 0.8743155 & 0.0665954 \\
\hline & & 0.225 & & 0.9990771 & 0.0612226 & 0.9646486 & 0.0046853 & 0.9577294 & 0.8394703 & 0.1168310 \\
\hline & \multicolumn{3}{|c|}{ Mean } & 0.9988 & 0.0471 & 0.5403 & 0.0029 & 0.9717 & 0.8813 & 0.0555 \\
\hline & \multicolumn{3}{|c|}{ Standard dev. } & 0.0010 & 0.0209 & 0.2939 & 0.0032 & 0.0260 & 0.0201 & 0.0302 \\
\hline \multirow{12}{*}{ 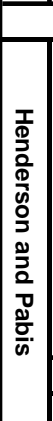 } & & & & $\mathrm{R}^{2}$ & DS & $E$ & $x^{2}$ & EF & $\bar{a}$ & $k, \min ^{-1}$ \\
\hline & \multirow{9}{*}{$\stackrel{i}{*}$} & 0.075 & & 0.9993807 & 0.0079428 & 0.0502113 & 0.0000688 & 0.9993110 & 0.9843853 & 0.0182052 \\
\hline & & 0.15 & 兵 & 0.9988434 & 0.0101970 & 0.1020793 & 0.0001178 & 0.9989725 & 0.9893929 & 0.0396841 \\
\hline & & 0.225 & & 0.9981857 & 0.0144552 & 0.1641015 & 0.0002469 & 0.9526025 & 0.9615895 & 0.0589130 \\
\hline & & 0.075 & & 0.9960040 & 0.0293437 & 0.1937349 & 0.0009431 & 0.9908417 & 0.9240671 & 0.0204076 \\
\hline & & 0.15 & 岁 & 0.9968115 & 0.0269167 & 0.0334044 & 0.0008360 & 0.9929394 & 0.9271083 & 0.0489899 \\
\hline & & 0.225 & & 0.9921539 & 0.0429008 & 0.5175501 & 0.0022086 & 0.9811822 & 0.8918234 & 0.0696549 \\
\hline & & 0.075 & & 0.9986533 & 0.0158813 & 0.1004542 & 0.0002788 & 0.9973352 & 0.9479160 & 0.0247651 \\
\hline & & 0.15 & 用 & 0.9992707 & 0.0181072 & 0.1690519 & 0.0003875 & 0.9966540 & 0.9475969 & 0.0599555 \\
\hline & & 0.225 & & 0.9952887 & 0.0387376 & 0.5038120 & 0.0018758 & 0.9830769 & 0.8954837 & 0.0958163 \\
\hline & \multicolumn{3}{|c|}{ Mean } & 0.9972 & 0.0227 & 0.2038 & 0.0008 & 0.9881 & 0.9410 & 0.0485 \\
\hline & \multicolumn{3}{|c|}{ Standard dev. } & 0.0022 & 0.0117 & 0.1716 & 0.0007 & 0.0140 & 0.0328 & 0.0242 \\
\hline
\end{tabular}



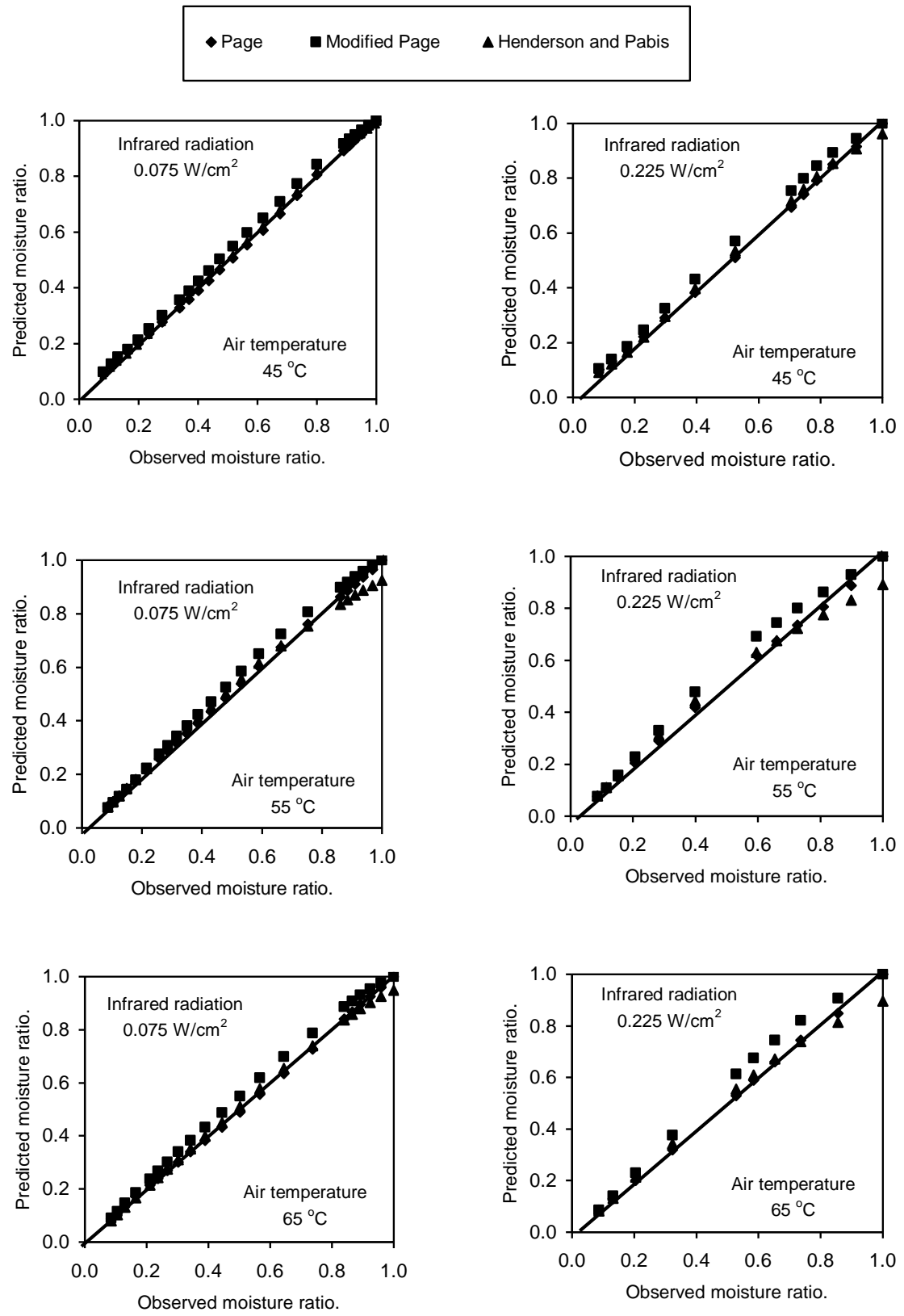

Figure (9): Observed and predicted moisture ratio of the combined heating mode for different studied models. 


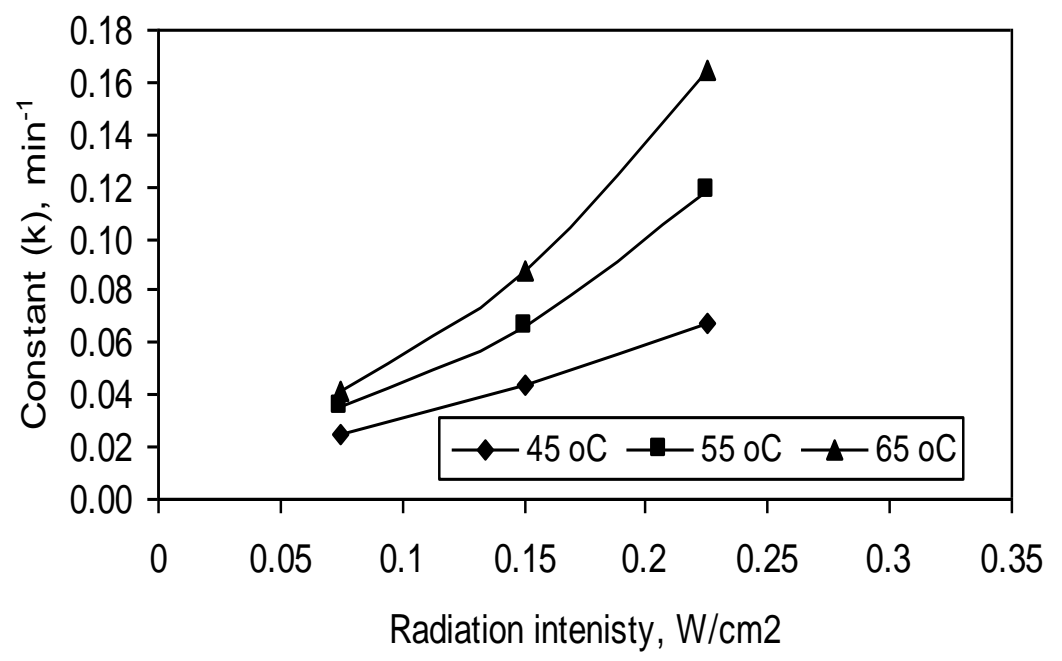

Figure (10): Drying constant (k) as related to radiation intensity and air

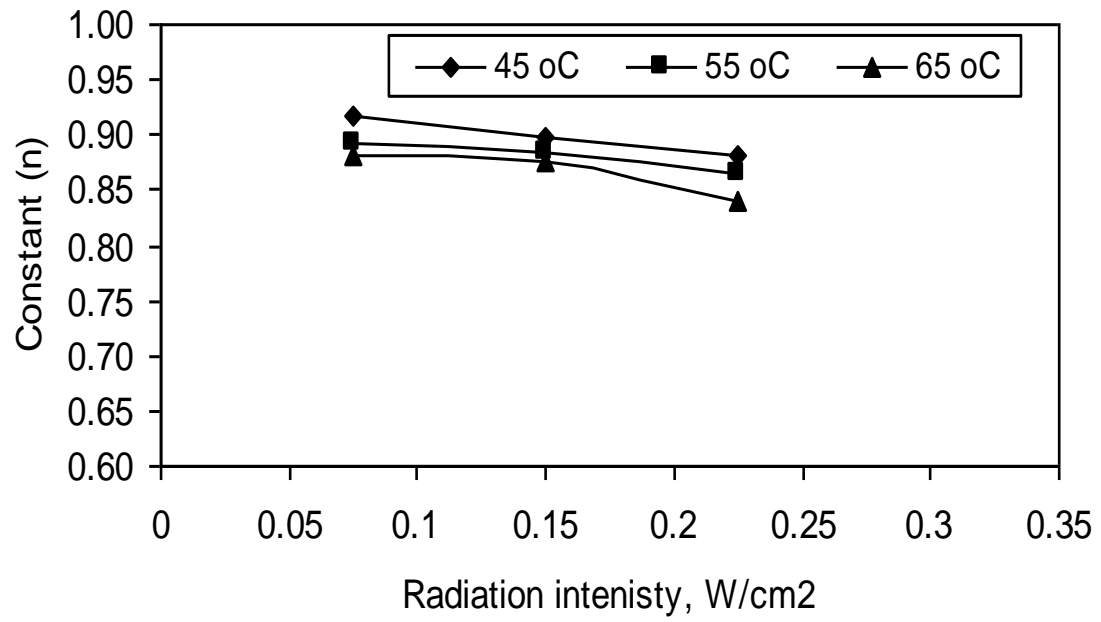

Figure (11): Drying constant (n)as related to radiation intensity and air 
the drying constants $(\mathrm{k})$ and $(\mathrm{n})$. The obtained relationships were as follows:

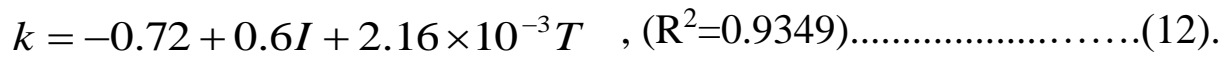

$$
\begin{aligned}
& n=1.47-0.224 I-1.69 \times 10^{-3} T \quad,\left(\mathrm{R}^{2}=0.9415\right) \ldots \ldots \ldots \ldots \ldots \ldots(13) .
\end{aligned}
$$

\section{Energy consumption:}

Figure (12) presents the effect of air temperature and air velocity on the specific energy consumption of the covection heating mode. As shown in the figure, the specific energy consumption decreased with the increase of air temperature and the increase of air velocity. Changing the air temperature from 45 to $75{ }^{\circ} \mathrm{C}$ at the minimum air velocity of $0.25 \mathrm{~m} / \mathrm{s}$ decreased the specific energy consumption from 41.37 to $17.78 \mathrm{MJ} / \mathrm{kg}$ water. While, at the maximum air velocity of $1.25 \mathrm{~m} / \mathrm{s}$ the specific energy consumption decreased from 73.8 to $50.91 \mathrm{MJ} / \mathrm{kg}$ water.

For the combined heating mode, Figure (13) shows that the specific energy consumption decreased with the increase of radiation intensity and the decrease of the air temperature. Changing the radiation intensity from 0.075 to $0.225 \mathrm{~W} / \mathrm{cm}^{2}$ at the minimum air temperature of $45{ }^{\circ} \mathrm{C}$ decreased specific energy consumption from 8.34 to $5.16 \mathrm{MJ} / \mathrm{kg}$ water. While, at the maximum air temperature of $\left(65^{\circ} \mathrm{C}\right)$ the specific energy consumption decreased from 14.58 to $5.37 \mathrm{MJ} / \mathrm{kg}$ water.

\section{Thermal Efficiency:}

Figure (14) presents the effect of different air temperature and air velocity on the thermal efficiency of the convection heating mode. As shown in the figure, the thermal efficiency increased with the increase of air temperature and the decrease of air velocity. Changing the air temperature from 45 to $75{ }^{\circ} \mathrm{C}$ at the minimum air velocity of $0.25 \mathrm{~m} / \mathrm{s}$ increased the thermal efficiency from 6.35 to $14.26 \%$ While, at the maximum air velocity of $1.25 \mathrm{~m} / \mathrm{s}$ it was increased 3.45 to $5.04 \%$. For the combined heating mode, Figure (15) shows that, thermal efficiency increased with the increase of radiation intensity and the decrease of air temperature. 


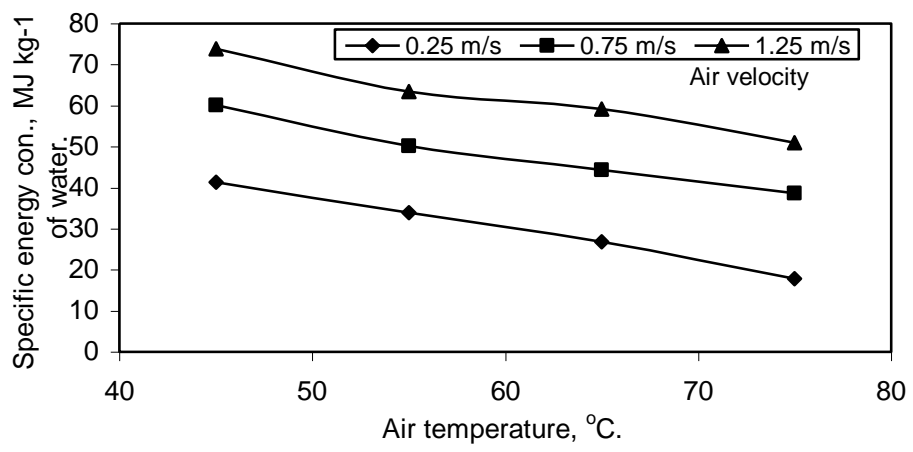

Figure (12): Effect of the air temperature on specific energy consumption of the convection mode at the different air velocity.

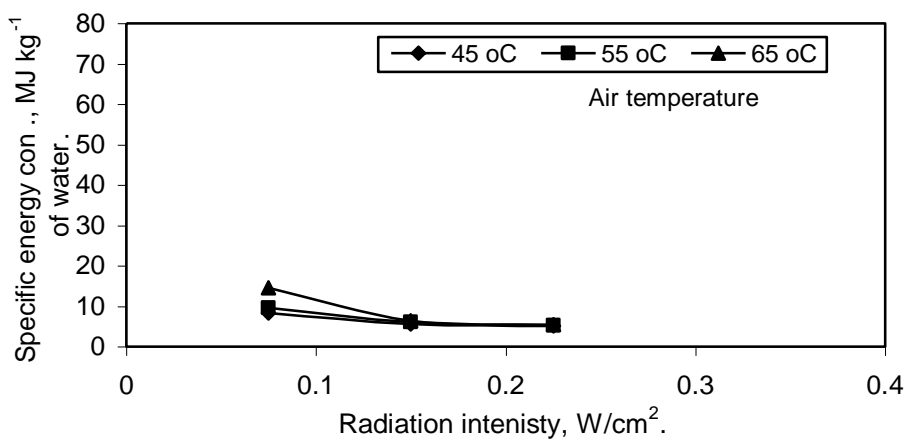

Figure (13): Effect of the radiation intenisty on specific energy consumption of the combined mode at the different air temperature.

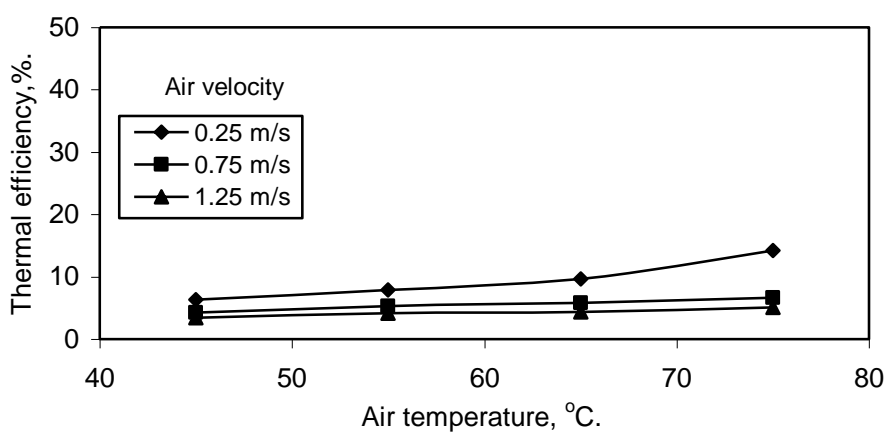

Figure (14): Effect of air temperature on the thermal efficiency of the convection mode at different air velocity. 


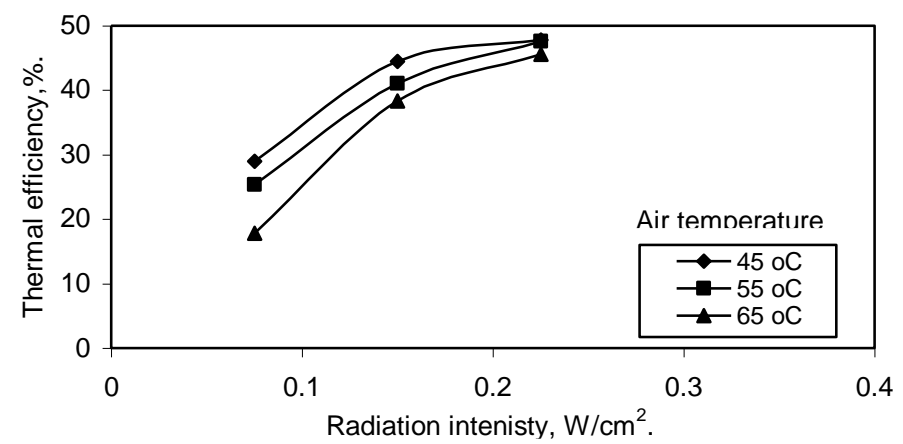

Figure (15): Effect of radiation intenisty on the thermal efficiency of the combined mode at different air temperature.

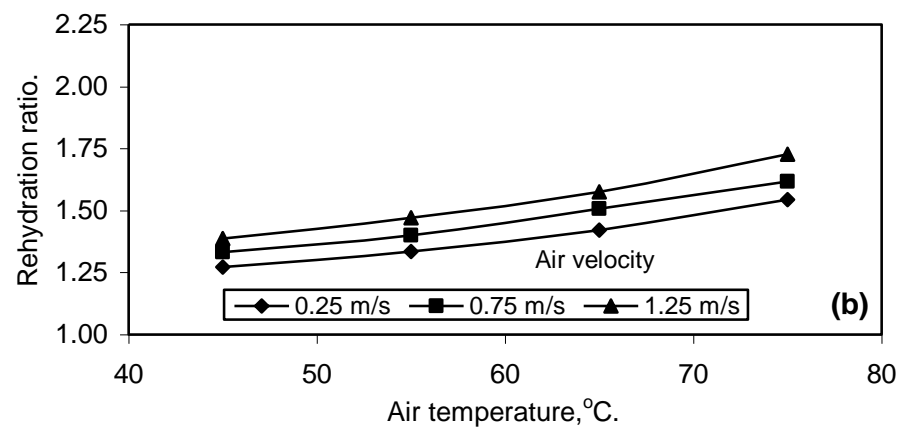

Figure (16): Effect of air temperature on the rehydration ratio of the convection mode at different air velocity.

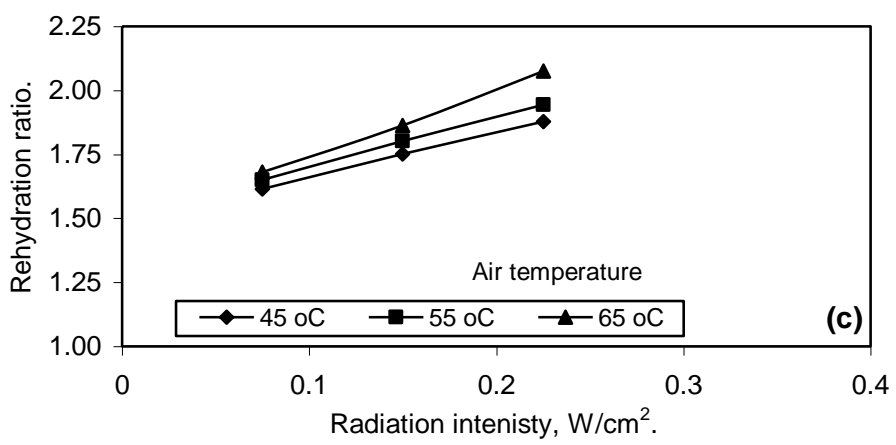

Figure (17): Effect of radiation intenisty on the rehydration ratio of the combined mode at different air temperature. 
At the minimum air temperature of $45{ }^{\circ} \mathrm{C}$ changing the radiation intensity from 0.075 to $0.225 \mathrm{~W} / \mathrm{cm}^{2}$ increased the thermal efficiency from 28.97 to $47.8 \%$. While, at the maximum air temperature of $65^{\circ} \mathrm{C}$ the thermal efficiency increased from 17.76 to $45.53 \%$.

\section{Quality of garlic slices:}

\section{Rehydration ratio:}

Figure (16) shows the effect of air temperature and air velocity on the rehydration ratio of garlic slices dried by the convection heating mode. The rehydration ratio increased by the increase of air temperature and air velocity. Changing the air temperature from 45 to $75^{\circ} \mathrm{C}$ at the minimum air velocity of $0.25 \mathrm{~m} / \mathrm{s}$ increased the rehydration ratio from 1.272 to 1.543. On the other hand, at the maximum air velocity of $1.25 \mathrm{~m} / \mathrm{s}$ the rehydration ratio increased from 1.387 to 1.638 . The increase of rehydration ratio with the increase of air temperature and air velocity may be due to less shrankage of the garlic slices. Meanwhile, for the combined heating mode, Figure (17) shows that, the rehydration ratio increased with the increase of radiation intensity and air temperature. Changing the radiation intensity from 0.075 to $0.225 \mathrm{~W} / \mathrm{cm}^{2}$ at the minimum air temperature of $45^{\circ} \mathrm{C}$ increased the rehydration ratio from 1.616 to 1.879 . While, at the maximum air temperature of $65{ }^{\circ} \mathrm{C}$ the rehydration ratio increased from 1.681 to 2.197 .

\section{Flavor strength:}

Figure (18) presents the effect of air temperature and air velocity on the flavor strength of garlic slices dried by the convection heating mode. The flavor strength increased with the increase of air temperature and the decrease of air velocity. Changing the air temperature from 45 to $75^{\circ} \mathrm{C}$ at the minimum air velocity of $0.25 \mathrm{~m} / \mathrm{s}$ increased the flavor strength from 3.2 to $3.51 \mathrm{mg} / \mathrm{g}$ dry matter. While, at the maximum air velocity of 1.25 $\mathrm{m} / \mathrm{s}$ the flavor strength increased from 3.01 to $3.39 \mathrm{mg} / \mathrm{g}$ dry matter. Decreasing the flavor strength by the increase of air velocity, may be due to fast and more addition of heat to the garlic slices. Meanwhile, for the combined mode Figure (19) shows that, the flavor strength decreased with the increase of radiation intensity and air temperature. At the minimum air temperature of $45{ }^{\circ} \mathrm{C}$ changing the radiation intensity from 0.075 to $0.225 \mathrm{~W} / \mathrm{cm}^{2}$ decreased the flavor strength from 4.56 to 4.21 


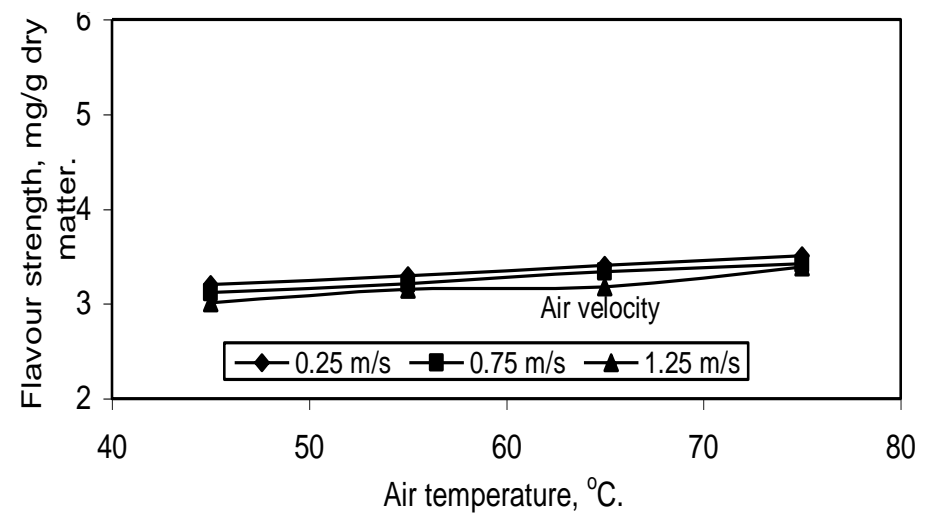

Figure (18): Effect of air temperature on the flavour strenght of garlic slices dried under the convection mode at different air velocity.

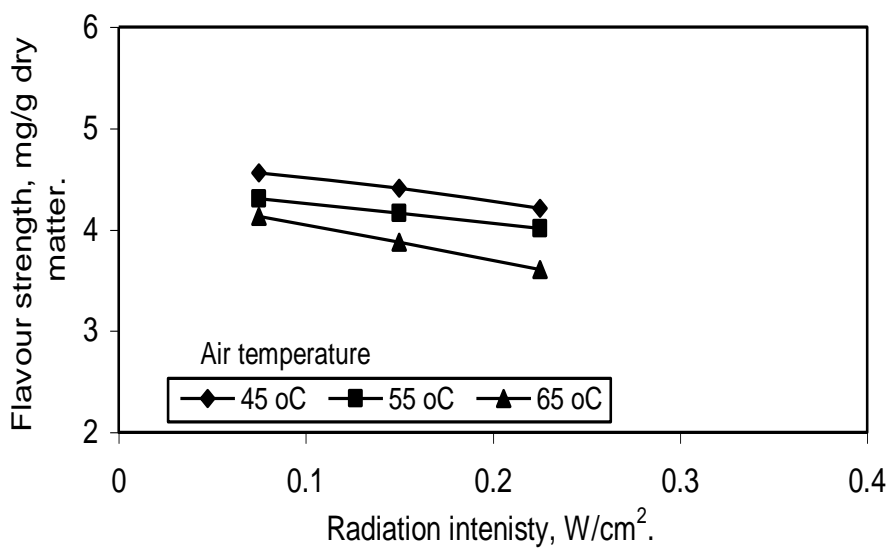

Figure (19): Effect of infrared radiation on the flavour strenght of garlic slices dried under the combined mode at different air temperature. 
$\mathrm{mg} / \mathrm{g}$ dry matter. While, at the maximum air temperature of $65{ }^{\circ} \mathrm{C}$ decreased the flavor strength from 4.13 to $3.61 \mathrm{mg} / \mathrm{g}$ dry matter.

\section{Colour of dried garlic slices:}

Figures (20 and 21) present the effect of air temperature and air velocity on the colour difference and the hue angle of garlic slices dried by convection heating mode. The colour difference increased and the hue angle decreased by the increase of air temperatureand and air velocity.

While, the colour difference increased and the hue angle decreased with the increase of radiation intensity and air temperature as shown in Figures (22 and 23).

\section{CONCLUSIONS}

Analysis of the results of the present research led to the following conclusions:

1- Drying rate, thermal efficiency, rehydration ratio, flavour strength and the colour difference were higher for the combined heating mode in comparison with the convection mode.

2- Drying time and specific energy consumption for the combined mode were lower than the convection mode.

3- Page model satisfactorily described the drying behaviour of garlic slices and predicted the changes in garlic slices moisture content.

For the combined heating mode, the drying constant (k) increased with the increase of radiation intensity and air temperature and the constant (n) decreased. While, for the convection heating mode, the drying constant (k) increased with the increase of air temperature and air velocity and the constant (n) decreased. 


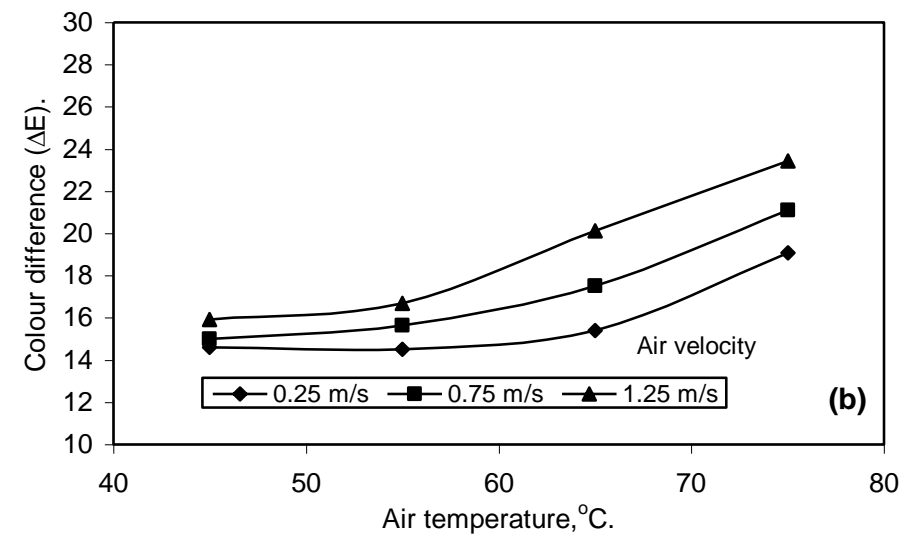

(20): Effect of air temperature on the colour difference at different air velocity.

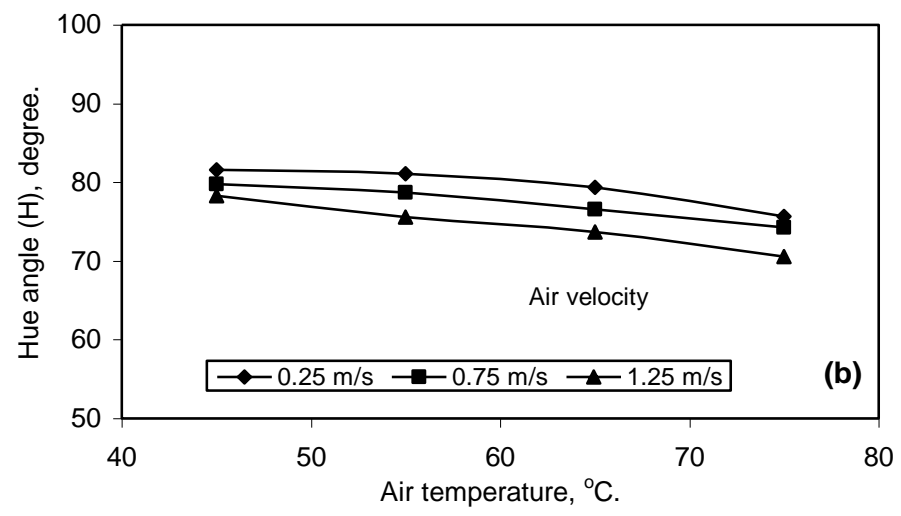

Figure (21): Effect of air temperature on the hue angle at different air velocity. 


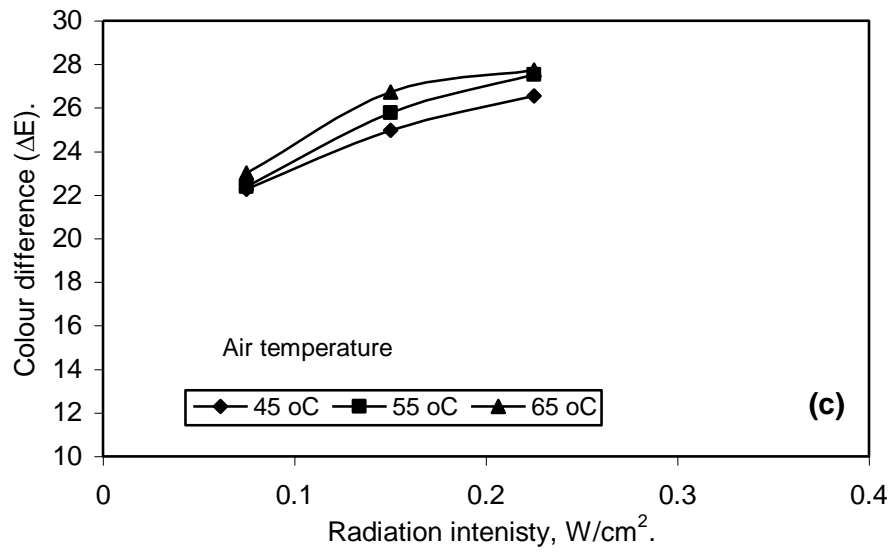

Fig. (22): Effect of infrared radiatiin on the colour difference of garlic slices dried under convection mode.

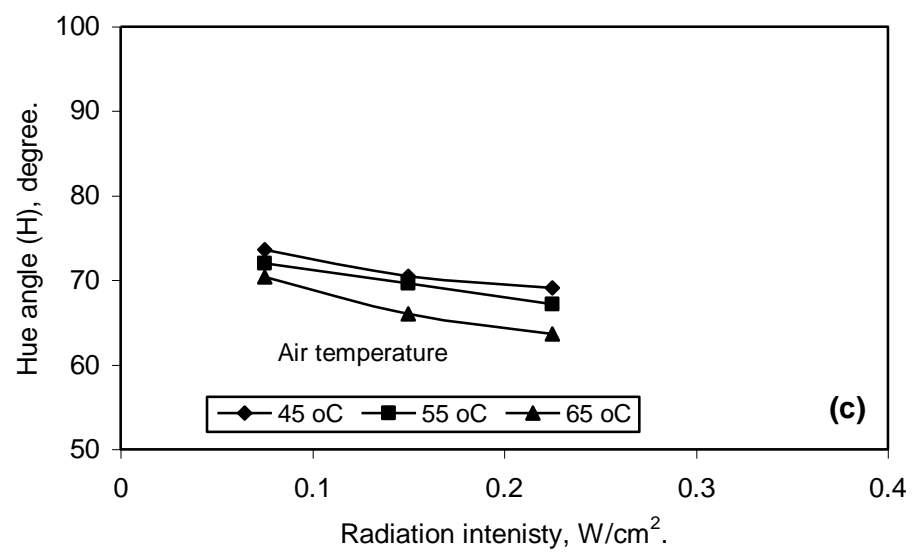

Fig. (23): Effect of radiation intenisity on the hue angle at different air temperature. 


\section{REFERENCES}

Abe, T. and M. Afzal (1997). Thin-layer infrared radiation drying of Rough rice. Journal of Agricultural Engineering Research, 67, 289-297.

Afzal, T. M. and T. Abe (2000). Simulation of moisture changes in barley during far infrared radiation drying. Computers and Electronics in Agriculture, 26, 137-145.

Afzal, T. M.; T. Abe and Y. Hikida (1999). Energy and quality aspects during combined FIR-convected drying of barley. Journal of Food Engineering, 42, 177-182.

A.O.A.C. (1995). Official method of analysis, association of official analytical chemists. Washington, D.C. USA.

Crank, J.(1975). The mathematics of diffusion. Oxford, England: Clarendon Press.

Dostie, M.; J. N. Seguin; D. Maure; Q. A. Ton-That and R. Chatingy (1989). Preliminary measurements on the drying of thick porous material by combinations of intermittent infrared and continuous convection heating. In A. S. Mujumdar and M. A. Roques (Eds.), Drying 89. New York: Hemisphere.

Doymaz, I (2004). Convective air drying characteristics of thin layer carrots. Journal of Food Engineering, 61, 359-364.

Ginzburg, A. S. (1969). Application of infrared radiation in food processing. Chemical process engineering series. London: Leonard Hill.

Hall, C. W. (1970). Drying farm crops. Agricultural Consulting Associates, Inc., Engineering sepecialists.

Headly, V. E., and C. W. Hall (1963). Drying of shelled corn vibrated in an infrared source. Transactions of the ASAE, 6(2), 148-150.

Hebbar, H.U.; K.H. Vishwanathan and M.N. Ramesh (2004). Development of combined infrared and hot air dryer for vegetables Journal of Food Engineering, 65, 557-563.

Henderson, S. M, and S. Pabis (1961). Grain drying theory. II. Temperature effects on drying coefficients. Journal of Agricultural Engineering Research, 6, 169-174. 
IIAS,(2007).Important indicators of agricultural statistics .Economics affairs sector, Ministry of Agricultural and Land Reclamation. volume 1(winter crops).

Jayas, D.S. and S. Sokhansanj (1989). Thin-layer drying of barley at low temperatures. Can. Agric. Eng. 31, 21-23.

Jones, P. (1992). Electromagnetic wave energy in drying processes. In A. S. Mujumdar (Ed.), Drying '92 (pp.114-136). Amsterdam: Elsevier Science.

Madamba, P. S., R. H. Driscollb and K. A. Buckleb(1996). The thinlayer drying characteristics of garlic slices. Journal of Food Engineering, 29, 15 - 97.

Mongpraneet, S.; T. Abe and T. Tsurusaki (2002). Accelerated drying of welsh onion by far infrared radiation under vacuum conditions. Journal of Food Engineering, 55, 147-156.

Navari, P.; J. Andrieu and A. Gevaudan (1992). Studies on infrared and convective drying of non hygroscopic solids. In A. S. Mujumdar (Ed.), Drying '92 (pp. 685-694). Amsterdam: Elsevier Science.

Noomhorm, A. and L. R. Verma (1986). Generalized single layer rice drying models. Transaction of ASAE, 29(2), 587-591.

Overhults, D. G.; G. M. Whit; H. E. Hamilto and I. J. Ross (1973). Drying soybeans with heated air. Transactions of the ASAE, 16, 112-113.

Reys, V. G. and Jindal (1986). Heat treatment of high moisture paddy for temporary storage. D. E. Dissertation A. IT. Bangkok Thailand. Pp. 31- 38.

Pabis, S. and S.M. Henderson (1962). Grain drying theory. III The air grain temperature relationship. J. Agric. Eng. Res. 7, 21-28.

Page, G. E. (1949). Factors influencing the maximum rates of air drying shelled corn in thin layers. M.S. thesis. Department of Mechanical Engineering, Purdue University, Purdue, USA.

Parakash, S.; S. K. Jha and N. Datta (2004). Performance evaluation of balanced carrots dried by three different driers. Journal of Food Engineering., 62, 305-313. 
Sacilik, K. and G. Unal (2005). Dehydration Characteristics of Kastamonu Garlic Slices. Biosystems Engineering, 92 (2), 207215.

Shankaranarayana, M. L.; K. O. Abraham; B. Raghavan and C. P. Natrajan (1981). Determination of flavor strength in alliums (onion and garlic). Indian Food Packer, 35: (1), 3-8.

Sharma, G.P .and S. Prasad (2006). Optimization of process parameters for microwave drying of garlic cloves. Journal of Food Engineering 75: 441-446.

Tutuncu, M. A. and T. P. Labuza (1996). Effect of geometry on the effective moisture transfer diffusion coefficient. Journal of Food Engineering, 30, 433-447.

Yaldiz, O. and C. Ertekin (2001). Thin layer solar drying of some different vegetables. Drying Technology-An International Journal, 19, 583-596.

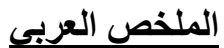

\section{تجفيف شرائح الثوم في طبقه رقيقة باستخدام نظام الحمل والنظام المختلط

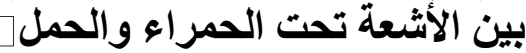

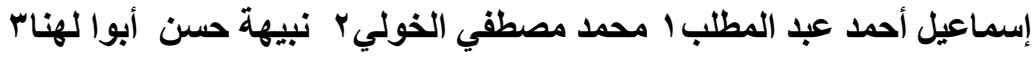

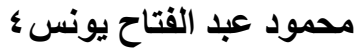

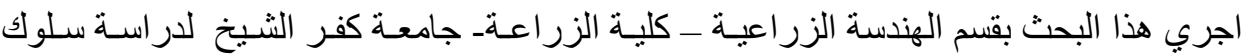

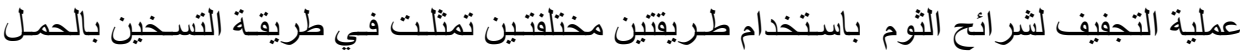

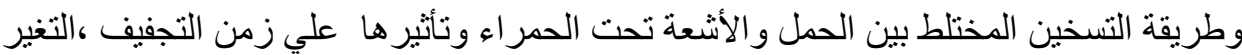

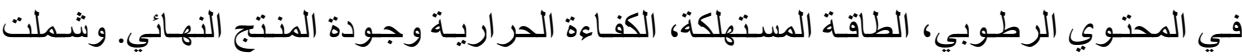

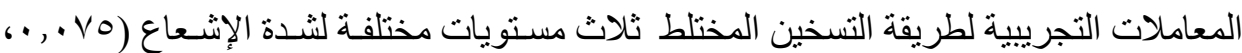

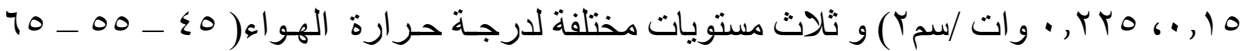

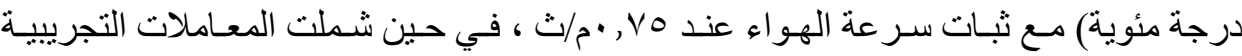

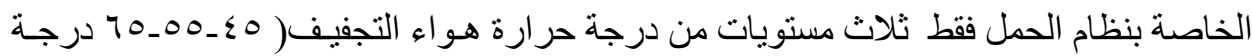

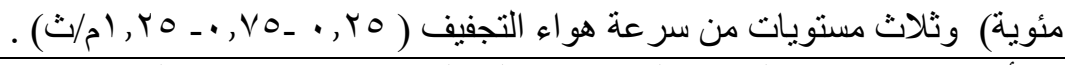

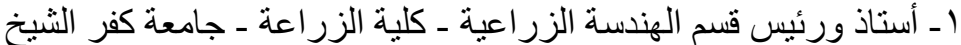

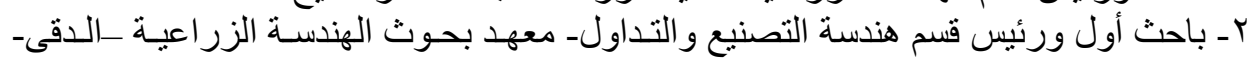
جيزة

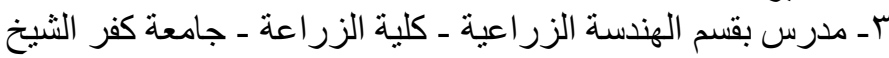

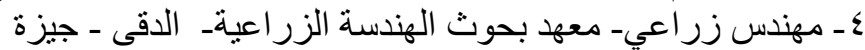


تم أيضا مقارنة ثلاث نماذج رياضية لوصف عمليـة التجفيف في طبقة رقيقـة لاختيـار الأفضل لوصف عملية التجفيف في كلا الطريقتنين.

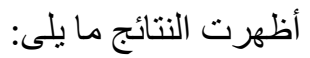

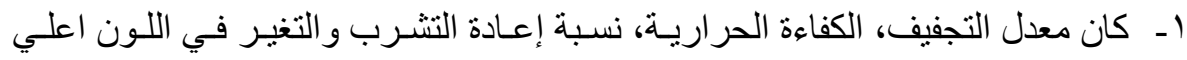

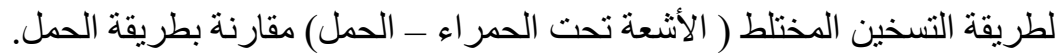

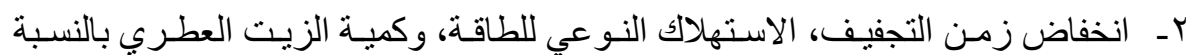

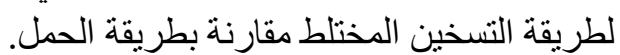

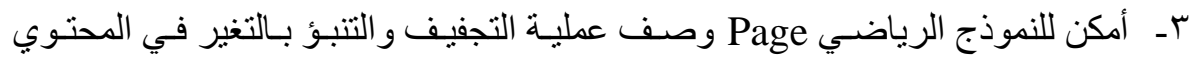

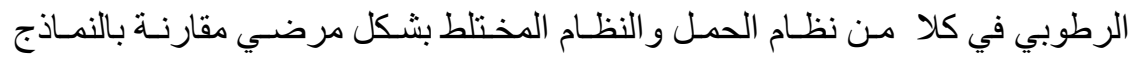

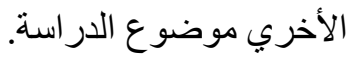

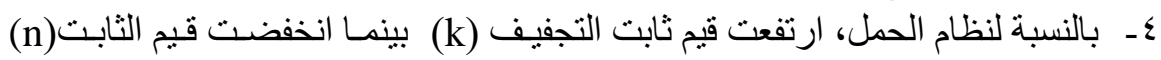

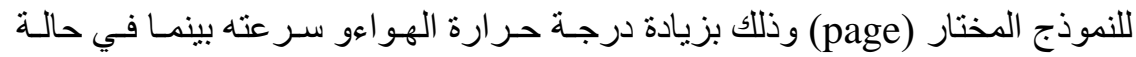

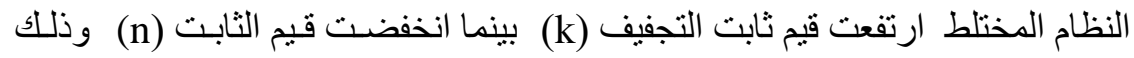
بزيادة شدة الإشعاع ودرجة الحرارة. 